\title{
PREDICTION OF FRACTURE ONSET IN FLASHLESS WARM FORGING MG ALLOY AZ61
}

\author{
PIOTR SKUbisZ *, LUKASZ LiSIECKI \\ AGH University of Science and Technology, al. Mickiewicza 30, 30-059 Krakow, Poland \\ ${ }^{*}$ Corresponding author: pskubisz@metal.agh.edu.pl
}

\begin{abstract}
The paper presents an innovative precision forging process, highlighting the use of advanced simulation of net forging process in multiple-tool die set with consideration of counter-pressure and interaction of components so as to control tool speed and displacement of metal. In addition to the use of finite element method in optimization of process conditions, damage criteria have been formulated to investigate the effect on plasticity and tendency of formation of defects and define process conditions which contribute to cracking occurrence in warm forging of magnesium alloy AZ61. Both forged samples and numerical simulation prediction indicate minimization of cracking hazard in lower work-temperature range at relatively high strain rate by employing counter-pressure imposing hydrostatic component into state of stress.
\end{abstract}

Key words: Magnesium alloy AZ61, Warm forging, Fracture criteria, Workability

\section{INTRODUCTION}

Specific advantages of magnesium alloys are generally known. So are their disadvantages (Avedesian, 1999), limiting potential use in civil, transport, military or aircraft engineering applications (Mordike \& Ebert, 2001). Extensive studies have been carried out over last decades with efforts to improve their key features, including cold and warm range workability. On account of flammability at increased temperature generated during machining (Kuczmaszewski et al., 2014) and reactivity to water (potential coolant), net shapes can be readily cast, which reduces the possibilities of strength enhancement, reducing range of application or more rarely, forged.

Cold or warm deformation is one of the most effective in strengthening of $\mathrm{Mg}$ alloys (Yoshida et al., 2005), but due to low intrinsic workability in low homologous temperature $\mathrm{Mg}$ alloys cannot be readily forged in warm and cold work regime, especially on machines prevailing in industrial conditions (Dziubińska et al., 2016). State of art in plastic forming indicate, however, there is a potential in plasticity enhancement to enable large plastic deformation, typical of forging. Hydrostatic extrusion (Świostek et al., 2006) or equal channel angular extrusion (Hilser et al., 2016) are most common in that respect, however, cross-section and sizes are limited or extruded geometry calls for machining. Forging is the process where complex state of stress and locally high strain-rate concentrations enhance both difficulties related to low workability and benefits associated with considerable reduction and favourable grain flow promoting directionality of properties. Both of the factors must be taken into consideration in design of forging technique and controlled in practice.

The presented work incorporates abovementioned conditions into net forging process to allow for low allowance shaping of thin-walled products featured by high strength by means of control of state of stress components. Employing counter-pressuredriven floating inserts enable forging at relatively low temperature on high-speed forging equipment, if the kinematic and geometrical parameters are properly 
set (Skubisz \& Sińczak, 2007). Although the concept of forging dates back a few years and since then has been patented and industrially implemented (Jakubowski et al., 2014), proper process conditions have been established with trial and errors method. With the development of advanced possibilities and more powerful PC units, numerical modeling with finite element method (FEM) can be used for optimization and definition of the most favourable kinematic parameters, defining sort of "processing window" for this process. The paper presents use of advanced simulation of forging process, including interaction of components in multiple-tool die set with consideration of counter-pressure so as to control speed and displacement of tools, which turned out the key factor in proper metal flow resulting in flawless forging. Its effect on plasticity and tendency of formation of defects is diagnosed by implementation of damage criteria, which allow localize onset of cracking and process conditions which contribute to its occurrence.

\section{ASSUMPTIONS AND MODELS}

\subsection{Models and boundary conditions in FEM simulation}

Graphical summary of the study including forging die set before and after forging, as well as location of the point of fracture, is presented in figure 1. The concept of the use of counter-pressure to control the metal flow in the die cavity is governed by balancing the pressures exerted by the displaced metal with that of the hydraulic, frictional or spring-held insert. However, since temperature, strain rate and strain degree change with progression of the forging stages, both area and forces of friction between work material and tool, as well, as between tool's components increase with ongoing displacement. In addition to that, characteristic of the hydraulic medium changes. These are only most obvious factors, which do not allow for determination the pressure counteracting the metal flow on the basis of the straight from the load/area relation. In this respect, numerical modeling with FEM can bring essential support. As long as reliable boundary conditions are assumed, finite element modeling enables parametric description of the pressure related to total force, which makes it possible to extend the use of this forging technique on a broad range of similar products.

Numerical computations were made with commercial code QFormVX, based on finite element method. The warm forging process involved viscoelastic-plastic model of deformed body. The simulation enabled close-to-real mirroring of changes of process parameters in consecutive time/strain increments, owing to employing thermo-mechanical coupled analysis. The friction law by Levanov is used in the model, with friction factor 0.35 assumed, as determined for the high-temperature oil lubrication (Skubisz, 2007) with Burgdorf ring compression method (Burgdorf, 1967; Wagener, 1994). Other boundary conditions assumed in simulation reflect actual process conditions. The most important are: tool energy $12 \mathrm{~kJ}$ with linear loss of $3 \mathrm{~kJ}$, based on screw press characteristics, heat transfer coefficient $75 \mathrm{~W} / \mathrm{m}^{2} \cdot \mathrm{K}$, emissivity coefficient 0.5 . The flow curves for the work material AZ61 were obtained from compression tests on Gleeble 3800 simulator (Skubisz, 2007).

\subsection{Ductile fracture models.}

Ductile fracture criteria generally have a form of an integral of a function, representing the effect of the process parameters over the strain range, as shown in the following equation:

$\int_{0}^{\varepsilon_{f}} f($ process parameters $) d \bar{\varepsilon}$

where: $\bar{\varepsilon}$ effective strain, $\bar{\varepsilon}_{f}$ - the equivalent or effective strain at failure, $f$ - some function of the process parameters (Jain et al., 1999).

In literature various ductile fracture criteria can be found for indication of failure onset in simulation of bulk metal forming operations (Pires et al., 2003; Gouveia et al., 1996). Fractures in forging mostly come up as ductile type of damage. They are based on the assumption that during plastic deformation a damage process, responsible for crack initiation occurs. In the warm-work range of magnesium alloy AZ61, the failure may incorporate features of localized sharebands mechanism, however it still is preceded by a plastic work (Korbel, 1986; Skubisz, 2007). Hence the idea of the work is to study applicability of Cockcroft \& Latham and Freudenthal (Freudenthal, 1950) ductile fracture criteria, which have been found reliable in prediction of fracture initiation in warm forging range (Lisiecki et al., 2015). 


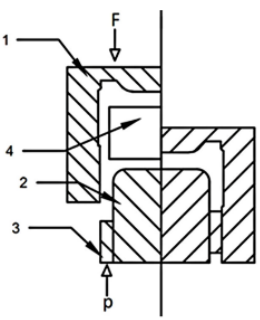

a)

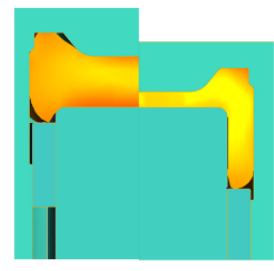

b)

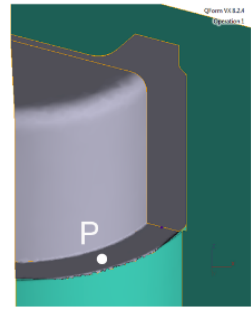

c)

Fig. 1. Graphical summary of the study: forging die set before and after forging (a), where 1-3 - die inserts, 4-billet, F, p - working pressures, numerical model of the process $(b)$, location of the point of fracture $(c)$.

In the presented work two fracture criteria were used which are based on different configuration of stress state concentration. Fracture criterion proposed by Freudenthal was one of the first damage model dedicated to metal forming processes. This criterion is a simple integration of effective stress with respect to the effective strain $\bar{\varepsilon}$. It can be interpreted as a deformation work criterion:

$\int_{0}^{\bar{\varepsilon}_{f}} \bar{\sigma} d \bar{\varepsilon}=C_{1}$

Another approach was proposed by Cockcroft \& Latham. For a given material, temperature and strain rate, they suggest that fracture occurs when the tensile stress (maximum principal stress $\sigma_{\theta}$ ) reaches a critical value

$$
\int_{0}^{\bar{\varepsilon}_{f}} \sigma_{\theta} d \bar{\varepsilon}=C_{2}
$$

The two approaches are used in the study so as to allow prediction of a risk of fracture considering different nature of material flow, which takes place in this case of forging process, featuring very high level of strain in the range of temperature resulting in nonuniform localization of strain (as revealed by microstructure analysis in work by Skubisz, 2007). Freudenthal's model is selected as it is focused on areas of high deformation work, prevailing in the volume of the sample, where critical value of plastic strain is easily achieved. Cockcroft \& Latham (CL) fracture criterion is focused on areas of tensile stress state domination (Christiansen et al., 2013), which is present in the analysed process, when the counterpressure is too low.

The limiting deformation was established in a compression tests at varied working temperatures. Sample dimensions were: diameter $15 \mathrm{~mm}$ and initial height $20 \mathrm{~mm}$. The temperature regime covered the range $200^{\circ} \mathrm{C}$ to $350^{\circ} \mathrm{C}$ with 50 degrees intervals.
Among all tested conditions, failure occurred in $200^{\circ} \mathrm{C}$ and $250^{\circ} \mathrm{C}$, whereas, in $300^{\circ} \mathrm{C}$ and $350^{\circ} \mathrm{C}$ no cracks were observed having reached final height of $5 \mathrm{~mm}$. With use of numerical simulation in QForm3D thermo-mechanical parameters observed were defined so as to determine $C_{1}$ and $C_{2}$ coefficients for the moment of fracture initiation. The limit values of the integrals $C_{1}$ and $C_{2}$, for $200^{\circ} \mathrm{C}$ and $250^{\circ} \mathrm{C}$, respectively, are 4,2 and 8.15 for Cockcroft \& Latham criterion (Lisiecki \& Skubisz, 2015) and 65 and 84 for Freudenthal. The determined values are of use in prediction of forgeability of AZ61 alloy in any pressforging process in reproducible strain-rate conditions. Figure 2 elucidates the concentration of the main component of the ductile fracture criteria, maximum principal stress in the moment of cracking onset and the form of the failure. Precise time of the crack initiation was established from the load-time plot recorded in compression test, as shown in figure 3. a)

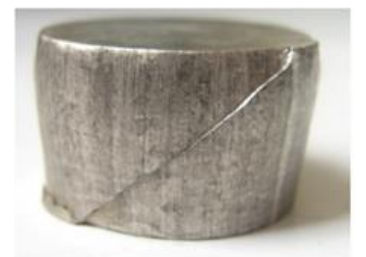

b)

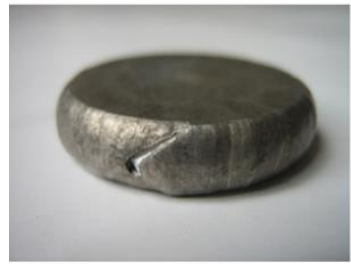

c)

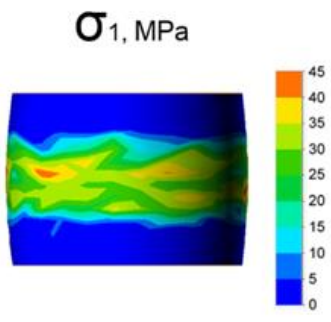

d)
Fig. 2. Fractures observed in compression tests $(a, c)$ and corresponding values of selected parameter involved in fracture criteria in the moment of cracking onset, calculated in simulation (b, d) for compression of AZ61 alloy in $200^{\circ} \mathrm{C}$ and $250^{\circ} \mathrm{C}$, respectively. 


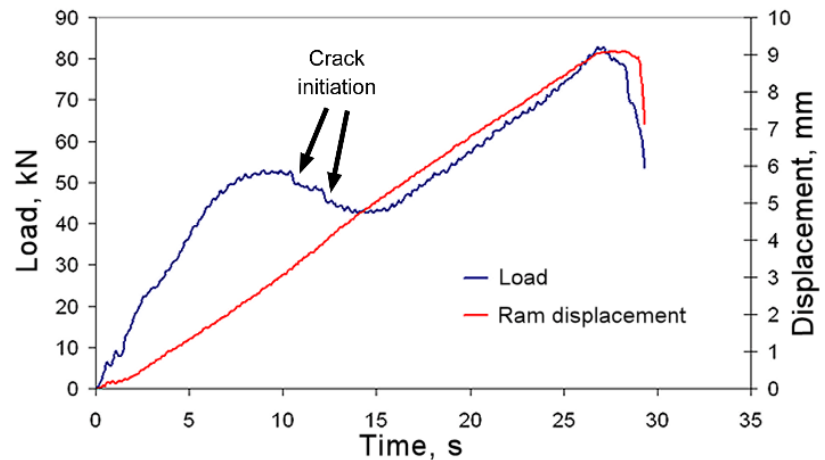

Fig. 3. Plot of load and displacement vs. time recorded in compression test at $200^{\circ} \mathrm{C}$ (Skubisz, 2007).

\section{RESULTS AND DISCUSSION}

\subsection{Effect of counter-pressure on die fillout}

By means of numerical simulation it was possible to analyze the history of crucial mechanical parameters in the bulk, which enabled comprehensive study of the effect of applied counter-pressure on the pattern of metal flow, especially laps occurrence and localization of the parameters to which fractures are attributed. In figure 4 evolution of geometry in consecutive stages of the single-stroke forging process is shown. It must be noted, that owing to the action of the counter-pressure driven floating insert it is possible to carry out whole deformation in a single blow, which is unachievable for similar shape complexity in conventional techniques, even for conventional materials, such as steels or aluminum alloys. What is more, floating insert allows compensation of the excess of material, hence it is referred to as compensator. a)

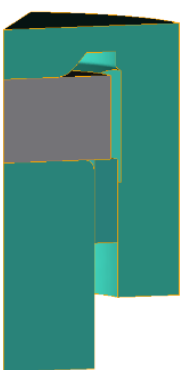

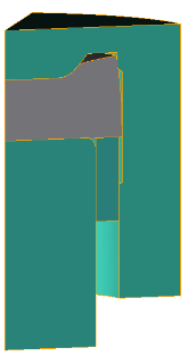

b)

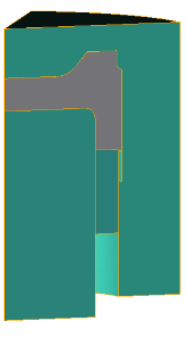

c)

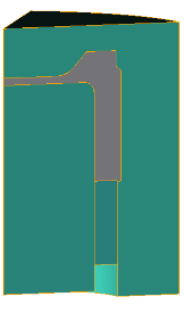

d)
Fig. 4. Sequence of consecutive stages of deformation and tool displacement during the forging process $(a-d)$.

Schematic of the investigated flashless forging technique lets conjecture that the metal flow and eventual result is highly vulnerable to the pressure balance between forged material and counter-pressure. The effect of the compensator pressure on soundness of the product can be seen even without stress analysis, by observation of underfillings. In figures 5 a to $5 \mathrm{~d}$ die-cavity fillout is presented, dependent on the counter-pressure value. As it can be concluded from the maps of contact surface, figures $5 \mathrm{a}$ and $5 \mathrm{~b}$ hardly differ, which means unit pressure as low as $0,01 \mathrm{MPa}$ does not really affect the metal flow. The shape thus obtained (figure 5b) exhibits underfilling similar to that of uncompressed insert (figure 5a). Significant meaning is observed over $0.02 \mathrm{MPa}$, where almost full shape is obtained. The fillout is actually full with action of $0.04 \mathrm{MPa}$, however, the pressure is reached, a small flash is being formed in the end stage of the press stroke.

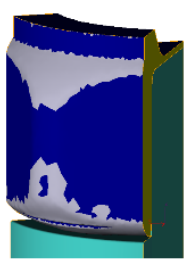

a)

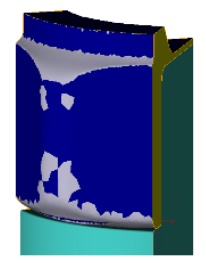

b)

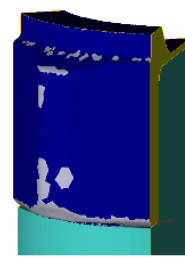

c)

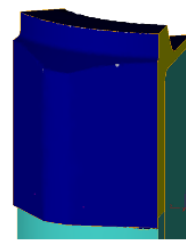

d)
Fig. 5. Maps of the metal-tool contact area calculated for unit pressure values: a) 0,001 MPa (uncompressed fluid), b) 0,01 $\mathrm{MPa}$, c) 0,02 MPa, d) 0,04 MPa of counter-pressure acting on compensator.

\subsection{Stress analysis.}

Besides complete fillout or underfilling of the die cavity, the presence of fractures contributes to general notion of soundness of the forged part. In accordance with the concept of the forging technique considered, warm-forging workability is enhanced by action of the counter-pressure, which is meant to introduce compressive components into state of stress in a point. As shown in figure 6 , correspondingly to increasing area of metal/tool contact, increase in absolute values of negative mean stress is observed, as well as the area subjected to hydrostatic state of stress. While the maps present end state, it is worth tracing the history of changes in a points most vulnerable to fracture occurrence. As shown in figure 7, increasing counter-pressure reduces tensile stress in the first stage of deformation, which can be concluded comparing mean stress plots in range 0.04 to 0.08 secs. The moment flow stress is balanced by unit pressure at compensator, mean stress reaches minimum of about -100 MPa, producing obvious plasticity improvement preventing from fracture formation with slight increase in total forging load (from $220 \mathrm{kN}$ to over $245 \mathrm{kN}$ ). 


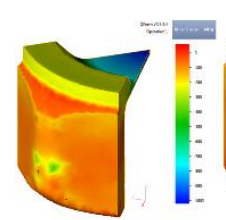

a)

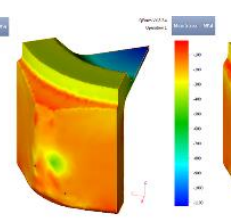

b)

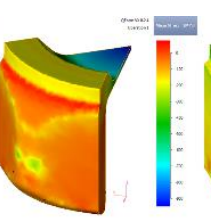

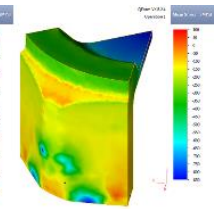

Fig. 6. Maps of mean stress distribution, calculated for unit pressure values: a) 0,001 MPa (uncompressed fluid), b) 0,01 $M P a, c)$ 0,02 MPa, d) 0,04 MPa of counter-pressure acting on compensator.

a)

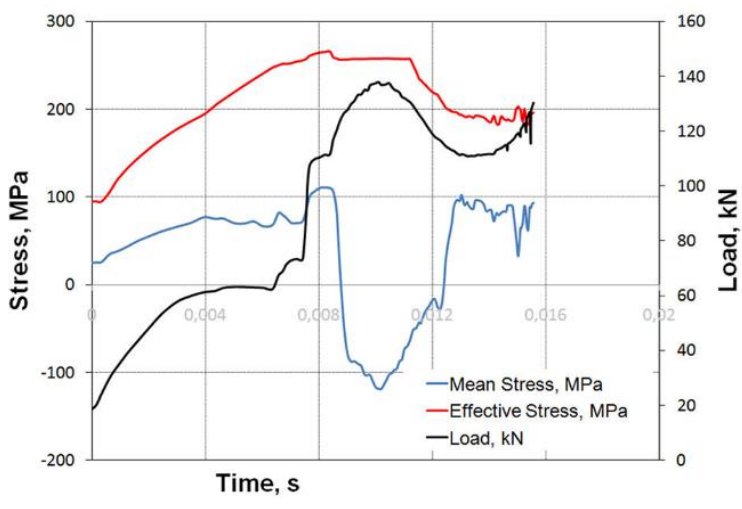

b)
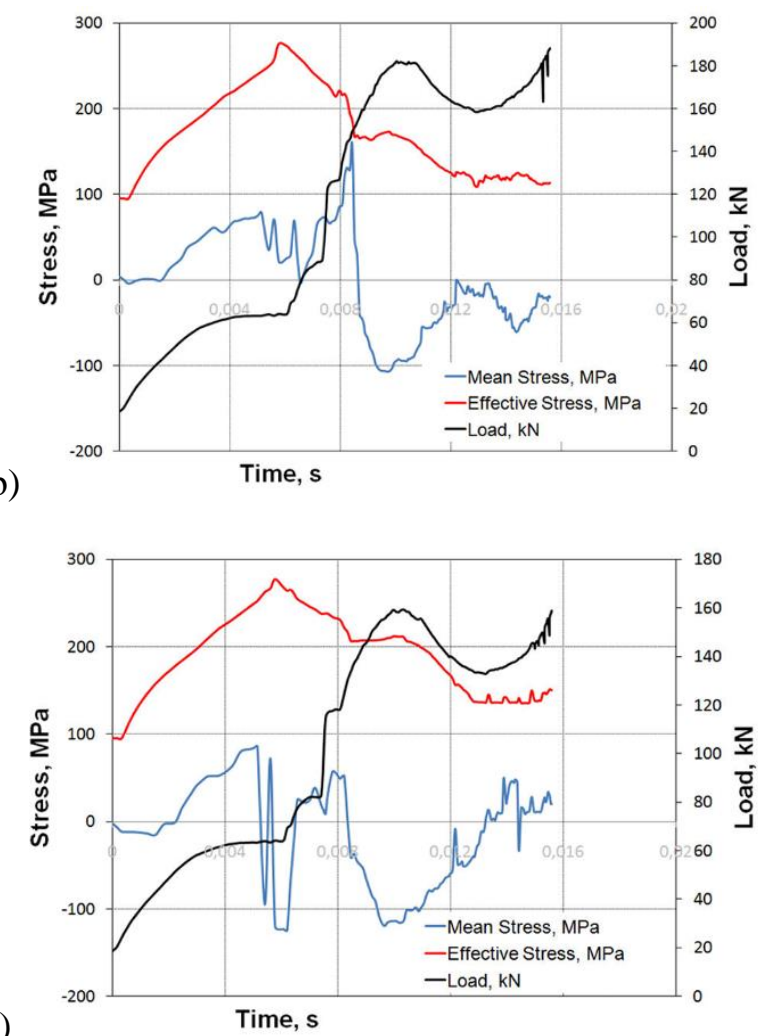

c)

Fig. 7. Plots of changes of effective stress, mean stress and forging load plots calculated in point $P$ with assumption of unit pressure values: a) 0,01 $\mathrm{MPa}$, b) 0,02 $\mathrm{MPa}$, c) 0,04 MPa.

\subsection{Fracture prediction.}

As expected, numerical analysis confirmed reduction of fracture hazard through employing a conterpressure-driven compensator. As indicated by CL criterion (figure 8a-c and figure 8e-g), owing to compressive stress component increase the material, is less inclined to rupture on the inside (figures $8 \mathrm{a}-\mathrm{c}$ ). At the same time, however, is more vulnerable to instable flow on the top inner edge (figure $8 \mathrm{~g}$ ). Assumptions of Freudenthal criterion tends to confirm credibility of CL criterion. As shown in Fig. 8 d), h), the failure hazard fields comply with one another, indicating potential rupture areas, which are confirmed confronting the simulation with experimental samples by the presence of separation in the samples (figure 9).

Physical realization of this process involved two cases: with and without hydraulically prestressed compensator. Both samples were forged on screw press at $200{ }^{\circ} \mathrm{C}$, which is warm work homologous temperature of AZ61 alloy, and ram speed changing from about 0,8 to $0 \mathrm{~m} / \mathrm{s}$. In figure $9 \mathrm{c}$, glittering spots can be noticed, which are folded fracture image, not observed in figure 9d. As shown in figures $9 a$ and $b$, the top of the part is in fact unaffected by the changes of counter-pressure value, although LC criterion suggest also flow instability on the inner fillet. Despite this, the prediction is credible, as it suggests threshold level of pressure which needs to be reached to counteract the action of generated tensile stresses on the free surface, expanded with the stroke progression. The effect of the counter-pressure is obvious, however, it is hard to estimate what was the actual pressure counteracting metal flow, especially, whether or not it had exceeded the values assumed in the simulation.

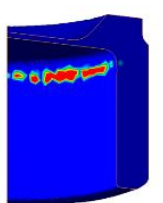

(a)

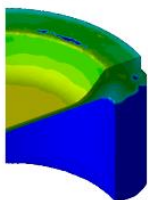

(e)

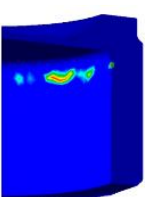

(b)

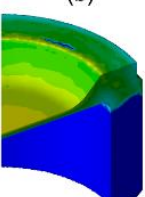

(f)

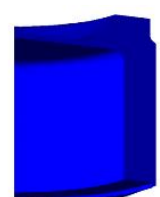

(c)

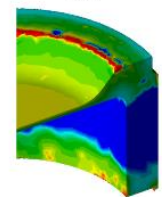

(g)

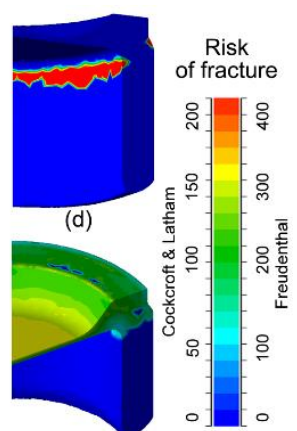

(h)
Fig. 8. Maps of distribution of relative hazard of ductile fracture initiation calculated with assumption of Cockcroft \& Latham model and unit pressure values: a) and e) 0,01 MPa,b) and f) 0,02 $\mathrm{MPa}, \mathrm{c}$ ) and g) 0,04 $\mathrm{MPa}, d$ ) and h) Freudenthal model for $0,01 \mathrm{MPa}$ unit pressure acting at compensator, in a bottom (ad) and a top view $(e-h$. 


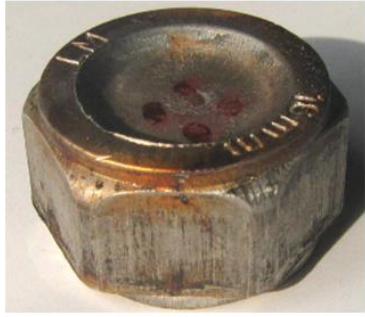

a)

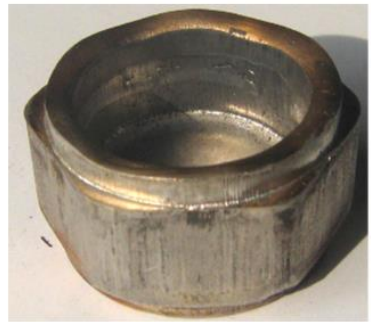

c)

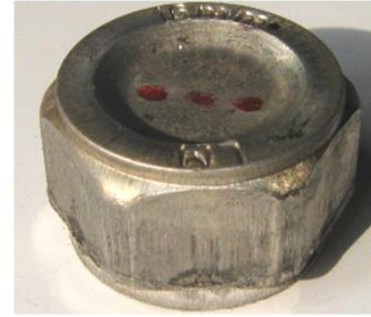

b)

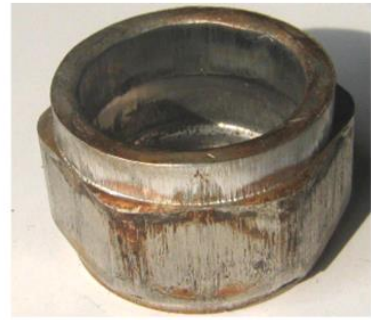

d)
Fig. 9. Forgings made of AZ61 without $(a, c)$ and with $(b, d)$ counteracting compensator.

\section{SUMMARY AND CONCLUSIONS}

The work indicates technical possibilities of screw-press forging of magnesium alloy AZ61, which is a hard to deformation material at warm and cold work temperature. Application of split dies with floating insert regulated by pressure balance enabled screw warm-forging range, thus making it possible to produce thin-walled precision forgings, assuming mechanical properties improvement (Skubisz, 2007). Key issue in this effort is the control of pressure balance between material and floating die.

The use of coupled thermo-mechanical analysis with interaction of components in multiple-tool die set, numerical simulation with FEM allows for selection and optimization of the process variables hard to be calculated from mechanical equations, especially optimization of the counter-pressure value in non-linear forging processes, which is conditioning the soundness and precision of the final product. Geometrical similarity to numerous engineering components or their sections make the guidelines representative and valid for wide range of applications.

The numerical analyses confirm the effect of utilization of hydraulic counterpressure on the material behavior during shaping of extremely complex part, providing parametric description of the pressure which can effectively counteract generation of principal main stress in the free surface of the deformed metal. As the maximum tensile stress is one of the main components of numerous fracture criteria, it also influenced the values of integrals calculated for the studied flashless forging process. The results suggest there is a threshold value of the pressure, above which the plasticity is improved to a degree making warm forging of magnesium alloy AZ61 possible at moderate rates of strain. The simulation results put into practice allowed verification of the assumptions and enabled realization of warm forging tests of AZ61 Mg alloy. The tests showed obvious effect of counter-pressure on plasticity and validated calculated dependence of this parameter on temperature related flow stress, thus controlling displacement of the floating insert. Inspection of forged samples obtained in physical tests confirmed the usability of the counterpressure in plasticity enhancement which makes it possible to produce sound forgings of magnesium alloy AZ61 at high forging speed.

\section{ACKNOWLEDGMENTS}

Financial support within MNiSzW research subsidy No. 16.16.110.663 is acknowledged.

\section{REFERENCES}

Avedesian, M.M., (ed.), 1999, ASM Specialty Handbook. Magnesium and Magnesium Alloys, The Materials Information Society, 314 .

Burgdorf, M., 1967, Über die Ermittlung des Reib-wertes für Verfahren der Massivum-formung durch den Ringstauchversuch, Industrie Anzeiger, 15-20.

Christiansen, P., Hattel, J.H., Bay N., Martins P.A.F., 2013, Modelling of damage during hot forging of ingots, Proc. 5th Int. Conf. STEELSIM, Ostrava, 42-54.

Dziubińska, A., Gontarz, A., Dziubiński, M., Barszcz, M., 2016, The forming of magnesium alloys forgings for aircrafts and automotive applications, Advances in Science and Technology Research Journal, 10(31), 158-168.

Freudenthal, A.M., 1950, The inelastic behavior of engineering materials and structures, 1st ed., John Wiley \& Sons Ltd., New York.

Gouveia, B.P.P.A., Rodrigues, J.M.C., Martins, P.A.F., 1996, Fracture criteria in bulk metal forming, International Journal of Mechanical Sciences, 38(4), 361-372.

Hilser, O., Rusz. S., Tanski. T., Snopinski. P., Dzugan. J., 2016, Krauss. M., Mechanical properties and structure of AZ61 magnesium alloy processed by equal channel angular pressing, Proc. 4th Int. Conf. Recent Trends in Structural Materials COMAT, Pilsen, 1-8.

Jain, M., Allin, J., Lloyd, D.J., 1999, Fracture limit prediction using ductile fracture criteria for forming of an automotive aluminum sheet, International Journal of Mechanical Sciences, 41, 1273-1288.

Jakubowski, K., Jakubowski, Ł., Sińczak, J., Skubisz, P., 2014, Patent No. PL 215668.

Korbel, A., 1986, Microscopic versus macroscopic aspects of shear bands deformation, Acta Metallurgica, 34(10), 19051909. 
Kuczmaszewski, J., Zagorski, I., Dziubinska, A., 2014, Investigation of ignition temperature, time to ignition and chip morphology after the high-speed dry milling of magnesium alloys, Aircraft Engineering and Aerospace Technology, 88(3), 389-396

Lisiecki, Ł., Skubisz, P., Karwan, J., 2015, Prediction and investigation of fracture initiation in warm forging of martensitic stainless steel with aid of FEM simulation, Computer Methods in Materials Science, 15, 246-352.

Lisiecki, Ł., Skubisz, P., 2015, Analysis of the impression-die forging process of hard-to-deformation magnesium alloys with regard to fracture occurrence, Rudy $i$ Metale Nieżelazne Recykling, 60, 12, 664-668 (in Polish).

Mordike, B.L., Ebert, T., 2001, Magnesium: Properties - applications - potential, Materials Science and Engineering A, 302, $37-45$.

Pires, F.M.A., Cesar de Sa, J.M.A., Costa Sousa, L., Natal Jorge, R.M., 2003, Numerical modelling of ductile plastic damage in bulk metal forming, International Journal of Mechanical Sciences, 45, 273-294.

Skubisz, P., Sińczak, J, 2007, Precision forging of thin-walled parts of AZ31 magnesium alloy, Archives of Metallurgy and Materials, 52(2), 329-336.

Skubisz, P., 2007, Determination of bulk forming conditions for $\mathrm{Mg}-\mathrm{Al}-\mathrm{Zn}$ magnesium alloys in warm-forming temperatures, Ph.D. thesis, AGH University of Science and Technology, Kraków, (in Polish).

Swiostek, J., Göken, J., Letzig, D., Kainer, K.U., 2006, Materials Science and Engineering A, 424, 223-229

Wagener, H.W., Wolf, J., 1994, Coefficient of friction in cold extrusion, Journal of Material Processing Technology, 44, 283-29.

Yoshida, Y., Arai, K., Itoh, S., Kamado, S., Kojima, Y., 2005, Realization of high strength and high ductility for AZ61 magnesium alloy by severe warm working. Science and Technology of Advanced Materials 6, 185-194.

\section{PROGNOZOWANIE PECKNIEĆ W PROCESIE KUCIA BEZWYPLYWKOWEGO NA CIEPLO STOPU MG AZ61}

\section{Streszczenie}

Praca dotyczy analizy wpływu zastosowania przeciwnacisku w procesie kucia dokładnego przy zastosowaniu bezwypływkowej metody opartej na równowadze ciśnień. Przedstawiona koncepcja narzędzi do kucia dokładnego metodą bezwypływkową jest innowacyjnym rozwiązaniem, które nie jest jeszcze dobrze rozeznane, zwłaszcza w zakresie optymalnego doboru parametrów kinematycznych procesu.

Odpowiednia konstrukcja matryc z ruchomymi wkładkami oraz dobór prędkości poszczególnych narzędzi, jak również wartości przeciwnacisków wywieranych przez elementy matryc składanych zapewniają zwiększenie plastyczności materiału, umożliwiając kucie bezwypływkowe w jednej operacji kucia. Pozwala to wytwarzać odkuwki porównywalne do kształtów uzyskiwanych na urządzeniach wielooperacyjnych typu Hatebur, eliminując obróbkę skrawaniem do niezbędnego minimum. Zapewniając poprawę plastyczności, umożliwia również kształtowanie materiałów trudnoodkształcalnych, takich jak stopy magnezu. Przedstawione wyniki kucia stopu magnezu potwierdzają możliwości wykorzystania tej techniki do kucia odkuwki cienkościennej ze stopu AZ61 w zakresie temperatur przeróbki na ciepło oraz jednoczesnych dużych prędkościach odkształcania.
Powodzenie kucia bezwypływkowego w układzie wielonarzędziowym, w przeciwieństwie do typowych procesów kucia bezwypływkowego nie zależy tylko od dokładnego doboru masy wsadu do kucia. Aby zapewnić optymalny schemat płynięcia metalu, prędkości narzędzi, wartość nacisków i przeciwnacisków kompensatora oraz jego położenie muszą być ściśle określone i kontrolowane w całym cyklu odkształcania. Stąd przedstawiona technika kucia, wymaga dokładnego sterowania parametrami procesu kucia. Z uwagi na obiektywne trudności kontrolno-pomiarowe, optymalizacja procesu w oparciu o próby fizyczne jest trudna. Zastosowanie technik komputerowych umożliwia analizę powiązań ciśnienia podtrzymującego kompensator ze zmianami plastyczności oraz zapewnia informacje poznawcze dotyczące wpływu przeciwnacisku na rozkład naprężeń i stanu naprężeń, pozwalając tym samym na parametryzację zmiennych procesowych. Jednocześnie, analiza numeryczna w programie QFormVX, umożliwiła powiązanie warunków procesowych z prognozowaniem ryzyka powstawania pęknięć w oparciu o kryteria Cockcrofta-Lathama i Freudenthala, które potwierdziły zasadność założeń konstrukcyjnych, wskazując zakresy najkorzystniejszych wartości przeciwnacisków.

Received: October 7, 2019 Received in a revised form: December 23, 2019. Accepted: December 27, 2019. 